\title{
Delineation of Saline Water Intrusion Lateral Extent Using Hydro-chemically and Geo-electrically Derived CRS - Model Parameters - A Case Study of Eastern Dahomey Basin, Nigeria
}

\author{
I.A. Adeyemo and G.O. Omosuyi \\ Department of Applied Geophysics, Federal University of Technology, Akure, Nigeria \\ $\left[{ }^{\star}\right.$ Corresponding Author: E-mail: iaadeyemo@futa.edu.ng; : : +234-8060042770]
}

\section{ABSTRACT}

This study was another attempt to map the subsurface lateral extent of saline water intrusions into aquifers at the eastern part of Dahomey basin, Nigeria. The study comprised geo-electric sounding method consisting of 108 vertical electrical soundings (VES) data acquired using Schlumberger array technique and hydro-chemical analysis of 61 water samples. The geoelectric survey results were presented as average longitudinal Conductance and average longitudinal Resistivity maps. The longitudinal conductance values vary from moderate to high (20 - 180 mhos) in the coastal areas, while lower values (lesser than 10 mhos) were recorded in the mainlands. Conversely the average longitudinal resistivity values were low to moderate $(0.26-41.7 \mathrm{ohm}-\mathrm{m})$ in the coastal areas and in few places such as Agbabu, Legbogbo and Sabomi in the mainland, while higher values (more than 60 ohm-m) were obtained from the mainlands. The hydro-chemical analysis results was presented as equivalent Salinity map; its values range from $25.8 \mathrm{mg} / \mathrm{l}$ (Ode-lrele) to $2808 \mathrm{mg} / \mathrm{l}$ (Asisa), high values were obtained from Ugbo, Ugbonla, Odonla, Idogun and Ayetoro area in the southeastern part of the study area and likewise at Agbabu in the north central part of the study area. The results were synthesized using CRS-model. The final CRS-model map showed that the saline water intrusion extended to $35 \%$ of the total area which covers; most part of the coastal area and Agbabu in the mainland.

Keywords: Saline water intrusion, saline-freshwater boundary, vertical electrical sounding (VES), hydrochemical analysis, synthesis and CRS-model.

\section{INTRODUCTION}

A major environmental problem regularly confronting continental areas adjoined by oceans is saline water intrusion into the coastal/continental aquifer. This has been reported by severally authors across the world [Choudhury et al., 2001; Chachadi et al., 2005; Batayneh, 2006; Khalil et al., 2006; MartinezRetama et al., 2007; Adepelumi, 2008; Samsudin et al., 2008; Oyedele and Momoh, 2009; Adeoti et al., 2010; Jansen, 2011; Satriani et al., 2011; Ayolabi et al., 2013; Rahaman and Bhattacharya, 2014; Adeyemo et al., 2015 and Adeyemo et al., 2017]. Very few works have been done on saline water Intrusions in the study area [Omosuyi et al., 2008; Omoyoloye et al., 2008; Adeyemo et al., 2015 and Adeyemo et al., 2017]. In all these previous works no model was generated for the determination of the saline water intrusion extent, while only two attempted to determine the saline water extent of the area [Adeyemo et al., 2015 and Adeyemo et al., 2017]. This study will be the first attempt to generate the saline water intrusion extent map in the study area using an appropriate scientific model which was generated by synthesizing the average longitudinal Conductance, average longitudinal Resistivity and equivalent Salinity values across the study area.

\section{The Study area}

The study area cut across six Local Government areas in the southern part of Ondo and Ogun States, South Western Nigeria. The area is located within the following coordinates; longitudes $4^{\circ} 22$ ' 22.5" $\mathrm{E}$ and 5010' $2.0^{\prime \prime} \mathrm{E}$ and latitudes $5^{\circ} 50^{\prime} 44.2^{\prime \prime} \mathrm{N}$ and $6^{\circ} 39^{\prime} 39.5^{\prime \prime} \mathrm{N}$ and it cover a total area of about $4,200 \mathrm{~km}^{2}$ (Figures 1 and 2). The area is generally characterized by flat and gently undulating topography. The elevations vary between 13 to $83 \mathrm{~m}$ above sea level in the mainland and 2 to $10 \mathrm{~m}$ in the coastal area (Figure 3). The study area is 
underlain by the sedimentary sequence of the Dahomey basin. The Dahomey Basin stretches from south-eastern Ghana to south-western Nigeria [Burke et al., 1971; and Klemme, 1975].

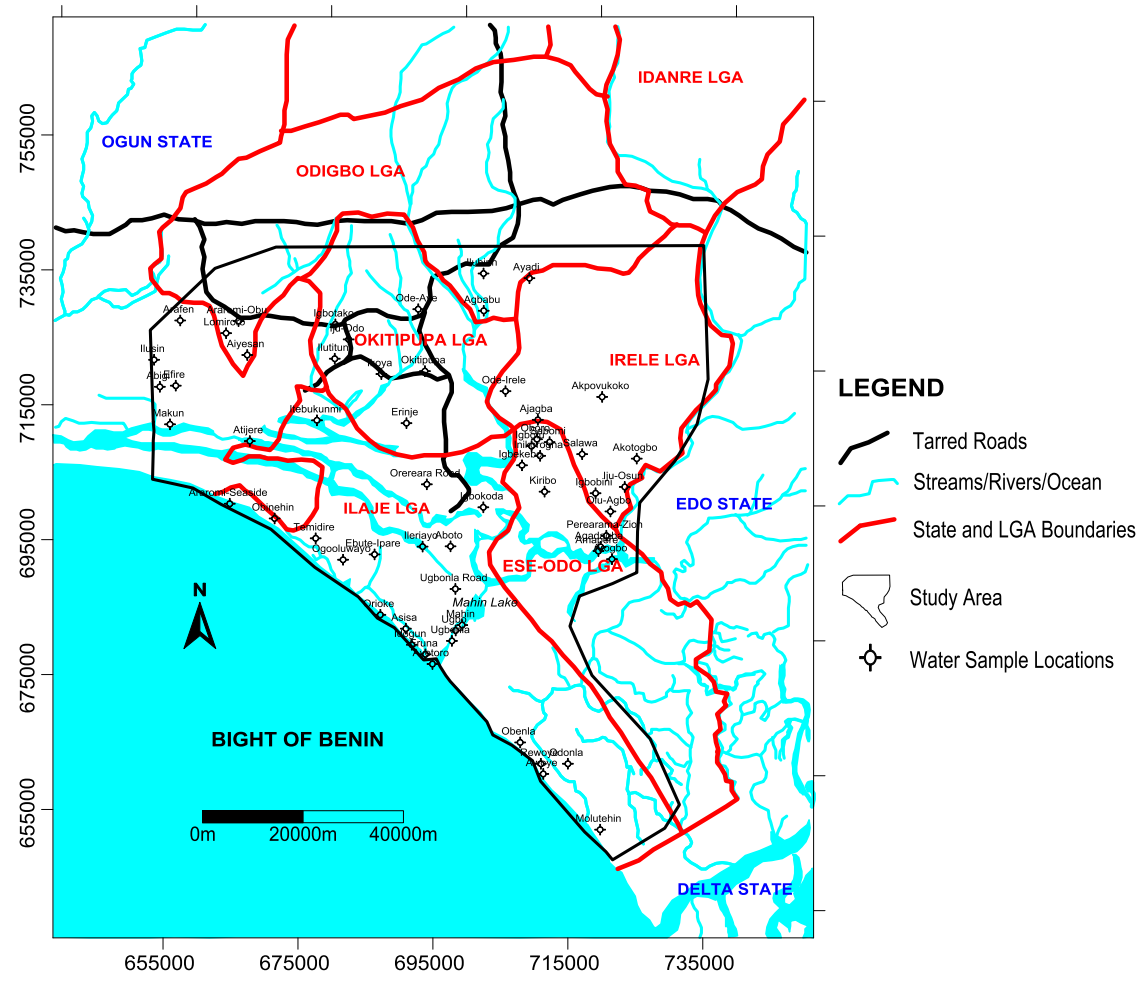

Figure 1: Location map of the study area showing water sampling locations.

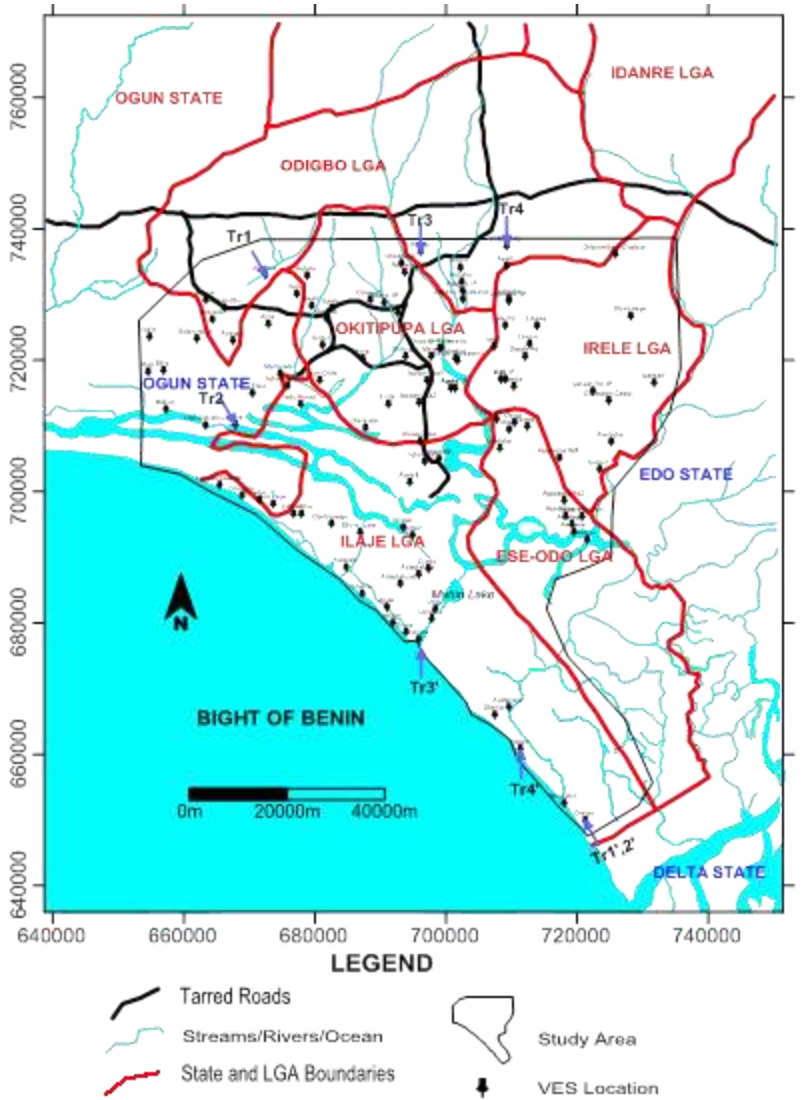

Figure 2: Location map of the study area showing VES locations 


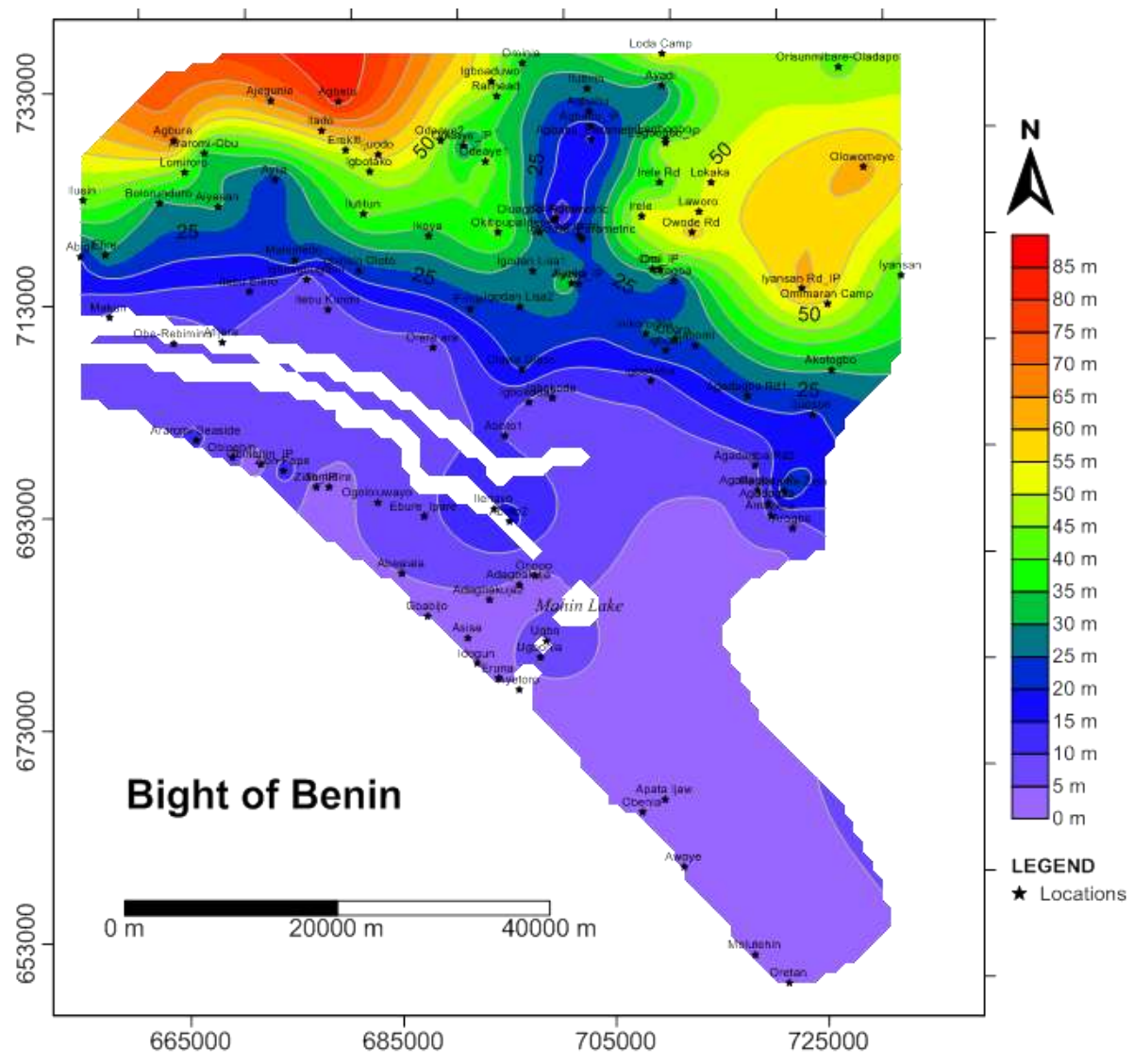

Figure 3: Topographic map of the study area

It is demarcated from the Niger Delta by Okitipupa Ridge (a subsurface structural ridge) around Okitipupa in Ondo State, Nigeria [Burke et al., 1971; Klemme, 1975; Omosuyi, 2001; Omosuyi et al., 2008]. Six lithostratigraphic units have been identified by various workers (Figure 4). The formations from the oldest to the youngest comprises; Abeokuta Group (Cretaceous), Ewekoro Formation (Palaeocene), Akinbo Formation (PaleoceneEocene), Oshosun Formation (Eocene), llaro Formation (Eocene) and Benin Formation (Oligocene-recent). The known aquifers in the study area are mostly within the Benin Formation [Burke et al., 1971; Okosun, 1998; Omosuyi et al., 2008] which consists of unconsolidated, poorly sorted sands with lenses of clayey shale [Okosun, 1998].

\section{METHODOLOGY}

The study integrated hydrochemical data and geoelectric parameters. A total of 61 (Figure 1) water samples were analyzed for 17 relevant parameters such as conductivity, $\mathrm{pH}$ value, total hardness, calcium hardness, magnesium hardness, total dissolved solids, total suspended solid, alkalinity concentration, and concentration of the following anions and cations; chloride, calcium, sulphate, bicarbonate, calcium, magnesium, sodium, manganese and nitrate. Equivalent salinity was also derived from the hydrochemical analysis results (Table 1). 108 vertical electrical soundings (VES) and data were acquired using Schlumberger array technique (Figure 2). The maximum current electrode separation $(\mathrm{AB} / 2)$ was varied from 225 to $750 \mathrm{~m}$. The field data were interpreted using the conventional partial curve matching technique supported with computer iteration. The VES results were presented in table 2 and different maps. 


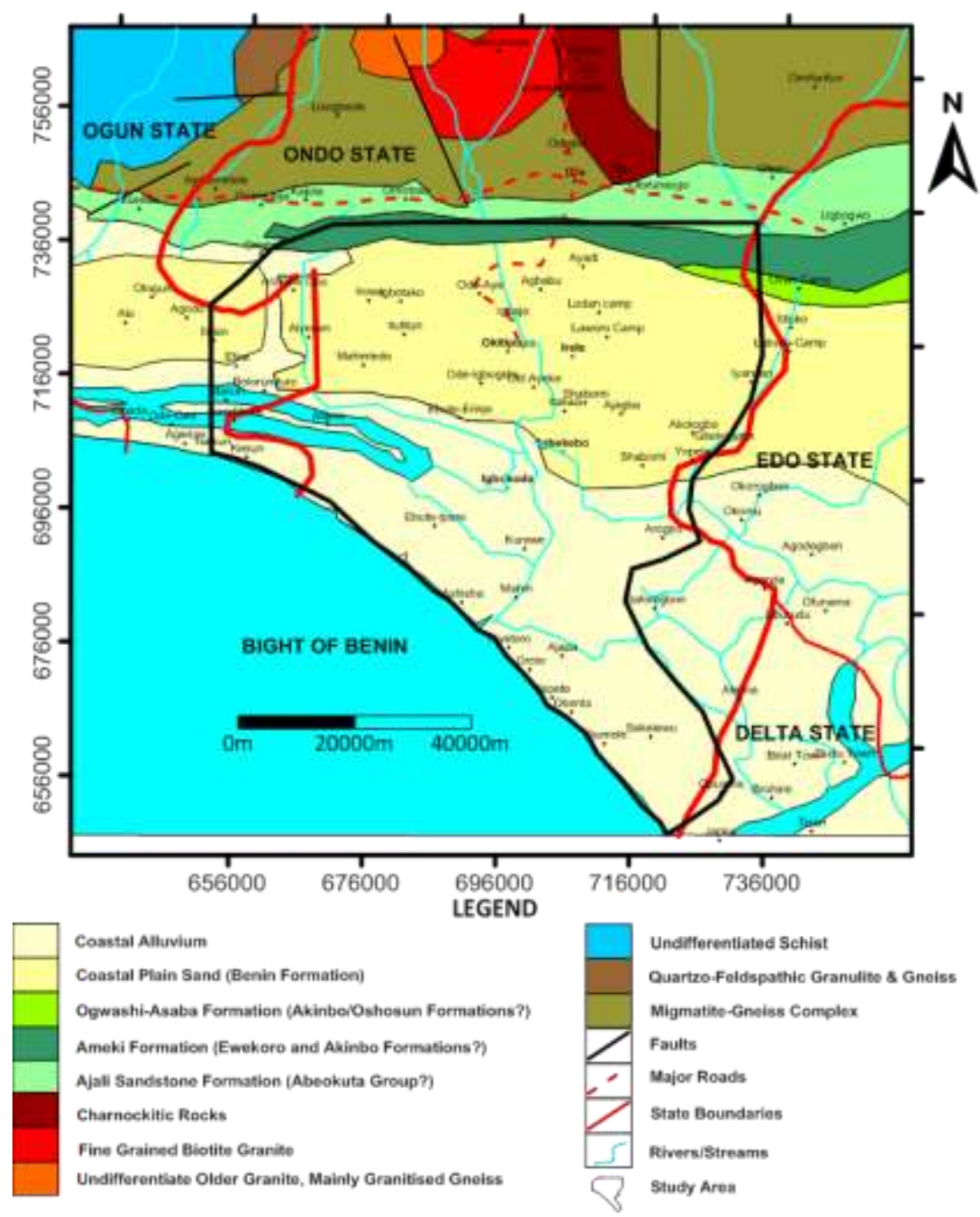

Figure 4: Geological map of the study area [Source: Nigeria Geological Survey Agency, 2004]

\section{RESULTS AND DISCUSSION}

The geo-chemical analysis results (Table 1) shows possible saline water intrusion in the coastal area and Agbabu in the north central area as evident from high concentration values of equivalent salinity $(135-2808 \mathrm{mg} / \mathrm{l})$. The VES results delineated three to seven layers. The layer resistivity values vary from 0.2 21806, 0.2 - 36762, 0.2 - 7958, 0.4 - 14243, 2 10798, $9-5285$ and $10-18527$ ohm-m in the topsoil, second, third, fourth, fifth, sixth and seventh geoelectric layers respectively. The eighth geoelectric layer was delineated only at Ode Aye 1 with resistivity value of 523 ohm-m. Layer thicknesses across the study area vary respectively from $0.4-10.6,0.1-58.6,0.5$ 206, $1.7-423.5,7.6-263$ and $81.2-133.5 \mathrm{~m}$ in the topsoil, second, third, fourth, fifth and sixth geoelectric layers respectively. At Ode Aye 1, the thickness value of the seventh layer is $\mathbf{1 5 . 2}$ m. Thirty-five (35) different curve types were delineated across the study area (Figure 5) varying from simple to complex types.

\section{Saline Water Lateral Extent}

The saline water lateral extent was determined by synthesizing the average longitudinal Conductance, average longitudinal Resistivity and equivalent Salinity values across the study area, the product is referred to as CRS-model. The synthesis was done using a previously used approach [Chachadi, 2005 and Adeyemo et al., 2017]. Each of these indicators was assigned weight based on their degree importance to occurrence of saline water. Each of these indicators was subdivided into different ratings; saline, brackish and fresh water and the 


\begin{tabular}{|c|c|c|c|c|c|}
\hline resu & f the weighting & nd rating factors were & 15 & Ikoya & 26.155 \\
\hline integ & d using the follc & ing relationship; & 16 & Ilutitun & 26.603 \\
\hline CRS & del value $=\{[$ & tlong_cond ${ }^{*} R t_{\text {long_cond] }}+$ & 17 & lju-Odo & 32.19 \\
\hline$\left[\mathrm{Wt}_{\mathrm{re}}\right.$ & ty ${ }^{*}$ Rtresistivity $]+[W$ & linity $\left.\left.{ }^{*} \mathrm{Rt}_{\text {salinity }}\right]\right\} \quad$ (1) & 18 & Igbotako & 34.895 \\
\hline Whe & & & 19 & Okitipupa & 45.776 \\
\hline$W t=$ & jight & & 20 & Igbokoda & 172.743 \\
\hline $\mathrm{Rt}=$ & & & 21 & Mahin & 78.136 \\
\hline & & & 22 & Ugbo & 315.229 \\
\hline Tabl & dro & alvcis Recults & 23 & Ugbonla & 720.72 \\
\hline & & Equivalent & 24 & Aboto & 42.451 \\
\hline S/N & Location & Salinity & 25 & Aiyesan & 38.7321 \\
\hline 1 & Ayadi & 42.152 & - & - & - \\
\hline 2 & Ode-Irele & 25.795 & 50 & Molutehin & 174.336 \\
\hline 3 & Igbobini & 35.488 & 51 & Awoye & 147.368 \\
\hline 4 & Olu-Agbo & 31.312 & 52 & Odonla & 243.96 \\
\hline 5 & Ugbonla Road & 26.4441 & 53 & Rewoye & 154.3401 \\
\hline 6 & Sabomi & 49.272 & 54 & Obenla & 134.816 \\
\hline 7 & Ajagba & 29.895 & 55 & Ayetoro & 168.305 \\
\hline 8 & Akpovukoko & 25.363 & 56 & Orioke & 2806.11 \\
\hline 9 & Akotogbo & 29.83 & 57 & Asisa & 2808.54 \\
\hline 10 & lju-Osun & 36.895 & 58 & Idogun & 1763.297 \\
\hline 11 & Agadagba & 30.892 & 59 & Eruna & 913.705 \\
\hline 12 & Amapere & 44.906 & 60 & Orereara Road & 55.2922 \\
\hline 13 & Igbekebo & 39.235 & 61 & Arogbo & 121 \\
\hline
\end{tabular}

based on the relationship below. The longitudinal unit conductance $\left(S_{i}\right)$;

$S_{i}=h i / \rho i$

Where,

$h_{i}=$ layer thickness

$\rho_{\mathrm{i}}=$ layer resistivity

While, for $\mathrm{n}$ layers the total longitudinal conductance is;

$\mathrm{S}=\sum_{i=1}^{n} \frac{h i}{\rho i}=\frac{h 1}{\rho 1}+\frac{h 2}{\rho 2}+\frac{h 3}{\rho 3}+\cdots+\frac{h n}{\rho n} \quad$ (Zhody et al., 1974)

The average longitudinal conductance map (Figure 6) reveals that the costal locations such as Obe-Rebiminu, Abealala, Gbabijo, Asisa, Idogun, Ayetoro, Eruna, Apata ljaw, Obenla, Awoye, Molutehin and Oretan recorded moderate to high longitudinal conductance values (20 - 180 mhos), while locations farther from the coastline recorded low longitudinal conductance values (lesser than 10 mhos). The map has a good correlation with the hydrochemical analysis results (Adeyemo et. al.,
2015) and the experience of the inhabitants of the area. Moderate to high longitudinal conductance values are expected at brackish/saline water intruded zones, since higher concentration of dissolved salt occurring in brackish/saline water intruded zones are associated with high conductivity. This map best describe the brackish/saline water intruded zone and hence the parameter was assigned the highest weight which is 6 (Tables 3 and 4). 
Nigerian Journal of Basic and Applied Science (December, 2017), 25(2): 28-40

Table 2: Vertical Electrical Sounding Results

\begin{tabular}{|c|c|c|c|c|}
\hline \multirow{2}{*}{$\begin{array}{l}\text { VES } \\
\text { No }\end{array}$} & \multirow[t]{2}{*}{ Location } & Resistivity ( $\Omega-\mathrm{m})$ & \multirow{2}{*}{$\begin{array}{l}\text { Thickness (m) } \\
D_{1} / D_{2} / D_{3} / \ldots \ldots \ldots . . . . D_{n}\end{array}$} & \multirow[t]{2}{*}{ Curve Type } \\
\hline & & $\rho_{1 /} \rho_{2 /} \rho_{3} \ldots \ldots \ldots \rho_{N}$ & & \\
\hline 1 & Omi & $1274 / 646 / 6170 / 369 / 7$ & $0.7 / 8.9 / 28.1 / 165.3$ & $H K Q$ \\
\hline 2 & Sabomi & $192 / 444 / 696 / 65 / 3763$ & $0.9 / 9.0 / 40.8 / 420.0$ & $\mathrm{AKH}$ \\
\hline 3 & Igbotu & $796 / 2012 / 860 / 757 / 69$ & $0.8 / 5.4 / 81.6 / 9.2$ & $K Q Q$ \\
\hline 4 & Agadagba & $4681 / 1800 / 153 / 31$ & $1.5 / 2.0 / 247$ & $\mathrm{QH}$ \\
\hline 5 & ljuosun & $76 / 118 / 290 / 1352 / 203$ & $0.9 / 1.9 / 17.9 / 65.2$ & AAK \\
\hline 6 & Akotogbo & $1349 / 2104 / 4745 / 1175 / 50$ & $0.6 / 5.9 / 38 / 80.8$ & $A K Q$ \\
\hline 7 & Ajagba & $1232 / 2062 / 396 / 59$ & $1.4 / 23.3 / 73.7$ & $K Q$ \\
\hline 8 & lgbekebo & $1333 / 631 / 1245 / 350 / 176$ & $0.6 / 4.2 / 19.0 / 80.6$ & $H K Q$ \\
\hline 9 & Asisa & $0.6 / 0.8 / 1.9$ & $2.7 / 143.9$ & A \\
\hline 10 & Obenla & $1.6 / 0.2 / 24 / 124$ & $4.4 / 20.2 / 31.7$ & $\mathrm{HA}$ \\
\hline 11 & Igbobini & $1372 / 662 / 3328 / 411 / 195$ & $0.8 / 3.0 / 16.5 / 169.8$ & $H K Q$ \\
\hline 12 & Oluagbo & $3024 / 145 / 631 / 428 / 206 / 5285$ & $0.7 / 0.1 / 12.4 / 2.8 / 64.4$ & $H K Q$ \\
\hline 13 & Irele & $709 / 142 / 876 / 8818 / 428 / 3243$ & $0.9 / 0.8 / 1.2 / 20.3 / 187.5$ & HAKH \\
\hline 14 & Laworo Camp & $157 / 762 / 386 / 4237 / 8522 / 119$ & $0.4 / 0.2 / 13.2 / 7.6 / 34.5$ & KHAK \\
\hline 15 & Lokaka Camp & $876 / 492 / 5844 / 878 / 1494$ & $1.0 / 1.0 / 1.4 / 116.5$ & $\mathrm{HKH}$ \\
\hline 16 & Owode Road & $843 / 824 / 6165 / 790 / 21$ & $1.2 / 5.0 / 22.2 / 276.8$ & $\mathrm{KKQ}$ \\
\hline 17 & Okitipupa & $1543 / 898 / 5416 / 113$ & $0.9 / 8.3 / 45.1$ & HK \\
\hline 18 & lkoya & $401 / 1276 / 41 / 568 / 4731$ & $0.5 / 1.7 / 0.5 / 25.9$ & $\mathrm{KHA}$ \\
\hline 19 & llutitun & $230 / 106 / 678 / 852 / 262$ & $0.8 / 7.8 / 10.6 / 43.6$ & HK \\
\hline 20 & Igbinsin Oloto & 4254/ 1128/3247/ 563 & $1.0 / 7.4 / 77.5$ & HK \\
\hline 21 & Igboegbugurin & $10608 / 821 / 1314 / 356 / 10798$ & $0.8 / 5.3 / 18.6 / 25.4$ & $\mathrm{HKH}$ \\
\hline 22 & Itebu Kunmi & $\begin{array}{l}21806 / 36762 / 2647 / 7925 / \\
1320\end{array}$ & $0.7 / 1.0 / 15.6 / 134.2$ & QHK \\
\hline 23 & Mahintedo & $1298 / 190 / 7958 / 757 / 175$ & $0.8 / 0.7 / 10.8 / 89.9$ & $H K Q$ \\
\hline 24 & Itebu Elero & $1457 / 476 / 1000 / 213 / 9675$ & $0.4 / 3.1 / 32.2 / 287.7$ & $\mathrm{HKH}$ \\
\hline 25 & Loda Camp & $197 / 3480 / 597 / 3739 / 623$ & $0.5 / 0.8 / 11.8 / 112.3$ & KHK \\
\hline 26 & Ayila & $350 / 1377 / 1121 / 291 / 56$ & $0.8 / 0.4 / 30.0 / 111.2$ & $K Q Q$ \\
\hline 27 & Aiyesan & $432 / 1154 / 392 / 2011 / 179$ & $0.8 / 1.5 / 2.7 / 62.0$ & KHK \\
\hline 28 & Lomiroro & $456 / 837 / 1258 / 2273 / 165$ & $0.8 / 5.2 / 11.3 / 49.3$ & AAK \\
\hline 29 & Efire & $56 / 1199 / 218 / 1551 / 434 / 82$ & $0.7 / 0.2 / 8.8 / 12.9 / 81.6$ & $\mathrm{KHKQ}$ \\
\hline 30 & Atijere & 3582/ 11265/4762/ 176/ 139 & $0.8 / 0.6 / 8.1 / 93.5$ & $\mathrm{KQQ}$ \\
\hline 31 & Makun & $2023 / 4007 / 2978 / 119 / 84 / 139$ & $0.7 / 2.8 / 7.0 / 13.1 / 97.4$ & $\mathrm{KQQH}$ \\
\hline 32 & Araromi-Obu & $2236 / 2592 / 6412 / 466 / 335$ & $0.9 / 13.5 / 51.0 / 24.9$ & $\mathrm{AKQ}$ \\
\hline 33 & Agbure & $1395 / 1296 / 2410 / 620 / 274 / 72$ & $1.3 / 3.5 / 24.7 / 14.7 / 123.7$ & HKQQ \\
\hline 34 & llusin & $1055 / 236 / 9179 / 717 / 71$ & $1.8 / 2.6 / 23.4 / 26.0$ & $\mathrm{HKQ}$ \\
\hline 35 & Abigi & $568 / 450 / 2084 / 297 / 56$ & $0.8 / 3.9 / 68.1 / 121.0$ & $H K Q$ \\
\hline- & - & - & - & - \\
\hline 105 & Adagbakuja2 & $0.9 / 0.6 / 0.9 / 7.4$ & $1.0 / 7.2 / 43.0$ & $\mathrm{HA}$ \\
\hline 106 & Oluagbo & Noisy data & & \\
\hline 107 & Agbabu2 & Noisy data & & \\
\hline 108 & Igbobini2 & Noisy data & & \\
\hline
\end{tabular}




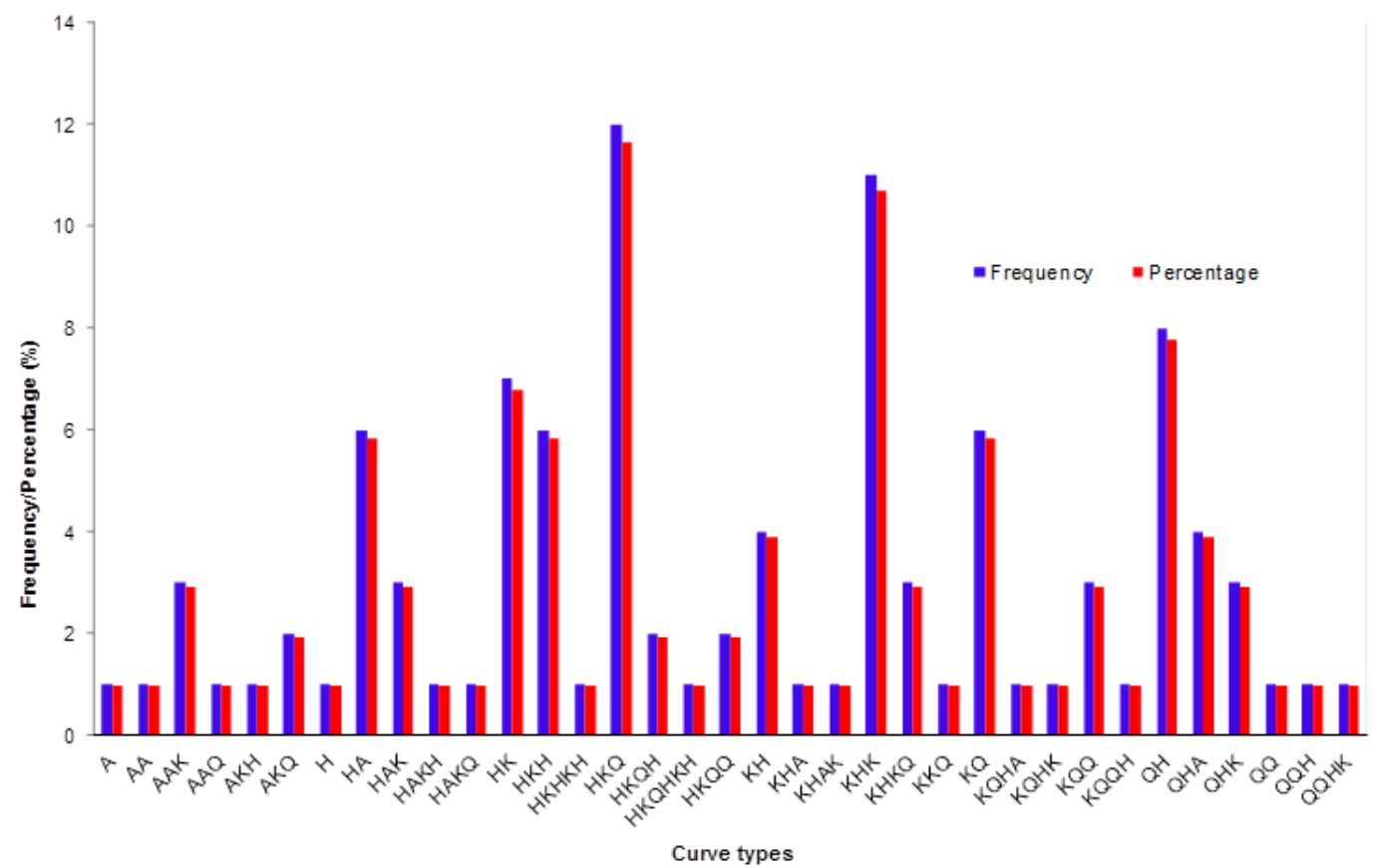

Figure 5: Curve types obtained from the study area and their rate of occurrence

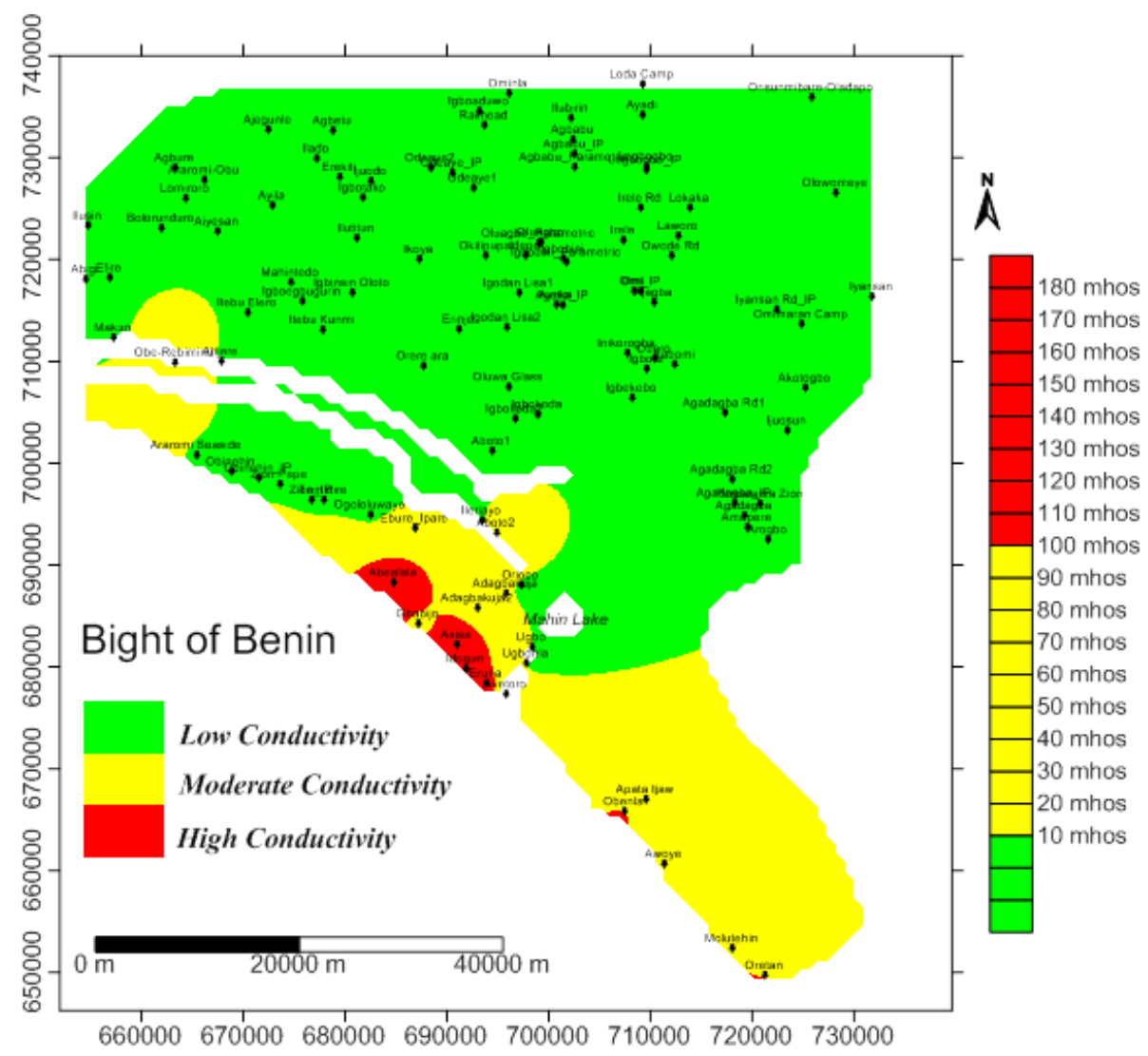

Figure 6: Map of average longitudinal conductance of the study area 
Table 3: CRS Indicator Weights

\begin{tabular}{lll}
\hline S/N & Factors & Weights \\
\hline 1 & $\begin{array}{l}\text { Average longitudinal } \\
\text { Conductance }\end{array}$ & 6 \\
2 & $\begin{array}{l}\text { Average longitudinal } \\
\text { Resistivity }\end{array}$ & 3 \\
3 & Equivalent Salinity & 1 \\
\hline
\end{tabular}

Table 4: Rating Adopted for CRS Parameter C

Indicator Factors Variables Ratings

\begin{tabular}{llll}
\hline & $\begin{array}{l}\text { Saline } \\
\text { water }\end{array}$ & $\begin{array}{l}\text { Above 100 } \\
\text { mhos }\end{array}$ & 1 \\
$\begin{array}{l}\text { Average } \\
\text { longitudinal } \\
\text { Conductance }\end{array}$ & $\begin{array}{l}\text { Brackish } \\
\text { water }\end{array}$ & $\begin{array}{l}10-100 \\
\text { zone }\end{array}$ & 1 \\
& $\begin{array}{l}\text { mhos } \\
\text { Fresh }\end{array}$ & Below 10 & \\
& water & $\begin{array}{l}\text { Ben } \\
\text { mhose }\end{array}$ & 0 \\
\hline
\end{tabular}

\section{Average longitudinal resistivity}

Average longitudinal resistivity map (Figure 7) is also useful in the delineation of brackish/saline water lateral extent across the study area. Resistivity value of any geologic material depends on the concentration of salt in its water content. Low longitudinal resistivity values (below $60 \mathrm{ohm}-\mathrm{m}$ ) were considered to be indicative of brackish/saline water zones in the area based on its good correlation with the hydro-chemical analysis results (Adeyemo et. al., 2015) and the experience of the inhabitants of the area. The average longitudinal unit resistivity was calculated from the first order

\section{Equivalent salinity}

Equivalent salinity was derived from calcium, sodium, chloride and sulphate concentrations based on the following relationship;
$0.81 \mathrm{Ca}+0.45 \mathrm{SO}_{4}+(\mathrm{Na}+\mathrm{Cl})$
(Agat
Laboratory, 2008)

geoelectric parameters based on the relationship below.

The average longitudinal unit resistivity $\left(\rho_{L}\right)$;

$\rho_{\mathrm{L}}=\mathrm{H} / \mathrm{S} \quad$ (Zhody et al., 1974)

Where,

$\mathrm{H}=$ sum of the total thickness of the layer beneath each VES point

$S=$ longitudinal conductance value for each VES point

While, for $\mathrm{n}$ layers the total average longitudinal conductance is;

$\rho_{\mathrm{L}}=\sum_{1}^{n} h_{i} / \sum_{1}^{n} \frac{h_{i}}{\rho \mathrm{i}}($ Zhody et. al., 1974) (5)

The average longitudinal resistivity map (Figure 4.23) reveals that the costal locations such as Obe-Rebiminu, Abealala, Gbabijo, Araromi Seaside, Obinehin, Zion Pepe, Asisa, Idogun, Ayetoro, Eruna, Apata ljaw, Obenla, Awoye, Molutehin and Oretan recorded low to moderate longitudinal resistivity values $(0.26-41.7 \mathrm{ohm}$ $\mathrm{m})$, Likewise Agbabu, Legbogbo and Sabomi in the northern part of the study area. Genearally locations farther from the coastline recorded high longitudinal resistivity values (more than 60 ohm-m). To a good extent the map described the brackish/saline water intruded zone, hence it was assigned a relatively high weight 3 (Tables 3 and 5).

Table 5: Rating Adopted for CRS Parameter R

\begin{tabular}{lllc}
\hline Indicator & Factors & Variables & Rating \\
\hline Average & Saline & $0-30$ & 1 \\
longitudinal & water & ohm-m & \\
Resistivity & $\begin{array}{l}\text { Brackish } \\
\text { water }\end{array}$ & $\begin{array}{l}\text { ohm-m } \\
\text { ohm }\end{array}$ & 1 \\
& $\begin{array}{l}\text { zone } \\
\text { Fresh }\end{array}$ & Above 60 & 0 \\
& water & ohm-m & \\
& zone & & \\
\hline
\end{tabular}

The equivalent salinity value is a direct reflection of subsurface water salinity. However the water samples were mostly collected at shallow depth from hand dug wells and surface water. This implies that where salinity occurs at 
relatively much depth, equivalent salinity will not reflect the salinity status of such locations. Thus equivalent salinity (Figure 8 ) was assigned the least weight, 1 (Tables 3 and 6 ). The equivalent salinity values range from minimum of $25.8 \mathrm{mg} / \mathrm{l}$ (Ode-Irele) to maximum of $2808 \mathrm{mg} / \mathrm{l}$ (Asisa).
The equivalent salinity map (Figure 8) shows that high values were obtained from Ugbo, Ugbonla, Odonla, Idogun and Ayetoro area in the southeastern part of the study area and likewise at Agbabu in the north central part of the study area.

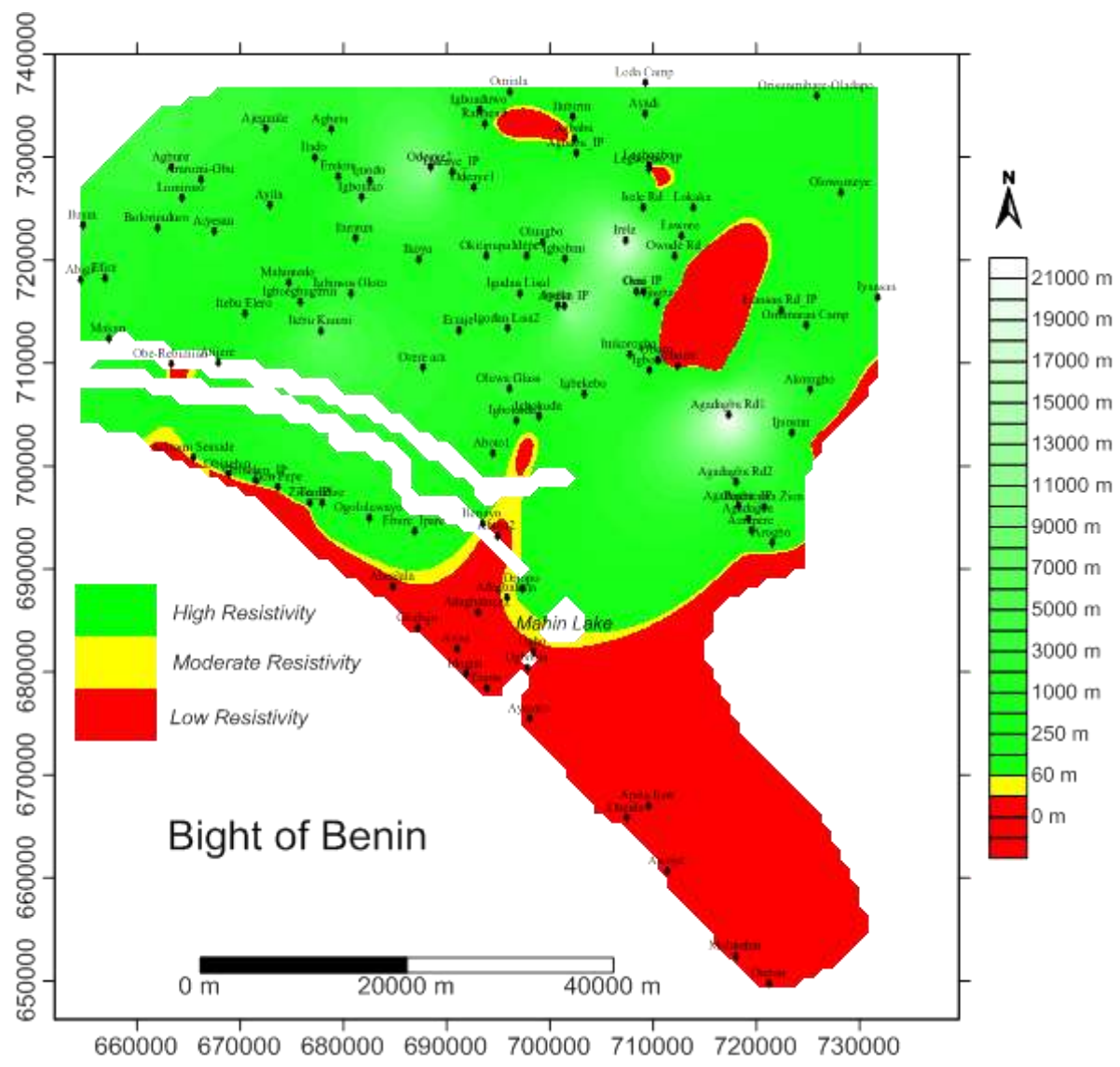

Figure 7: Map of average longitudinal resistivity of the study area

Table 6: Rating adopted for CRS parameter S

\begin{tabular}{llll}
\hline Indicator & Factors & Variables & Ratings \\
\hline Equivalent & Saline & Above & 1 \\
Salinity & water & $300 \mathrm{mg} / \mathrm{l}$ & \\
& Brackish & $200-300$ & 1 \\
& water & $\mathrm{mg} / \mathrm{l}$ & \\
& zone & & \\
& Fresh & Below & 0 \\
& water & $200 \mathrm{mg} / \mathrm{l}$ & \\
& zone & & \\
\hline
\end{tabular}

\section{Saline Water Extent Map}

Saline water extent map (Figure 9) was generated based on CRS-model. A model generated by synthesizing the average longitudinal Conductance, average longitudinal Resistivity and equivalent Salinity values across the study area (Table 7). The map project with high degree of accuracy the possible extents of saline water incursion across the study area and this represents about $35 \%$ of the study area. The map shows that the southeastern part are the largely affected by saline water intrusion, this perhaps due to the fact that there are more tributaries in this area through which sea water can move land ward. 
Nigerian Journal of Basic and Applied Science (December, 2017), 25(2): 28-40

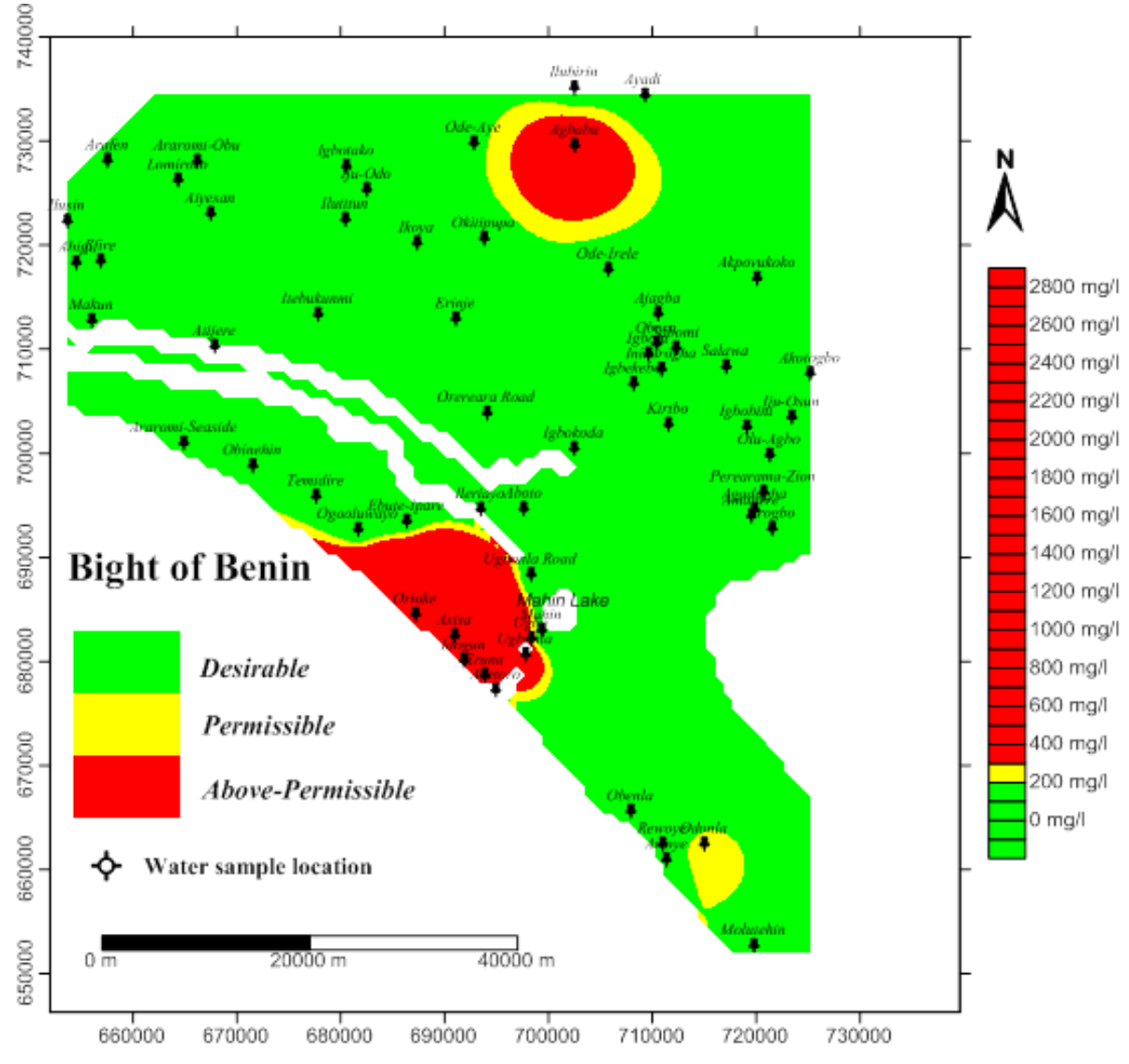

Figure 8: Equivalent salinity map of the study area.

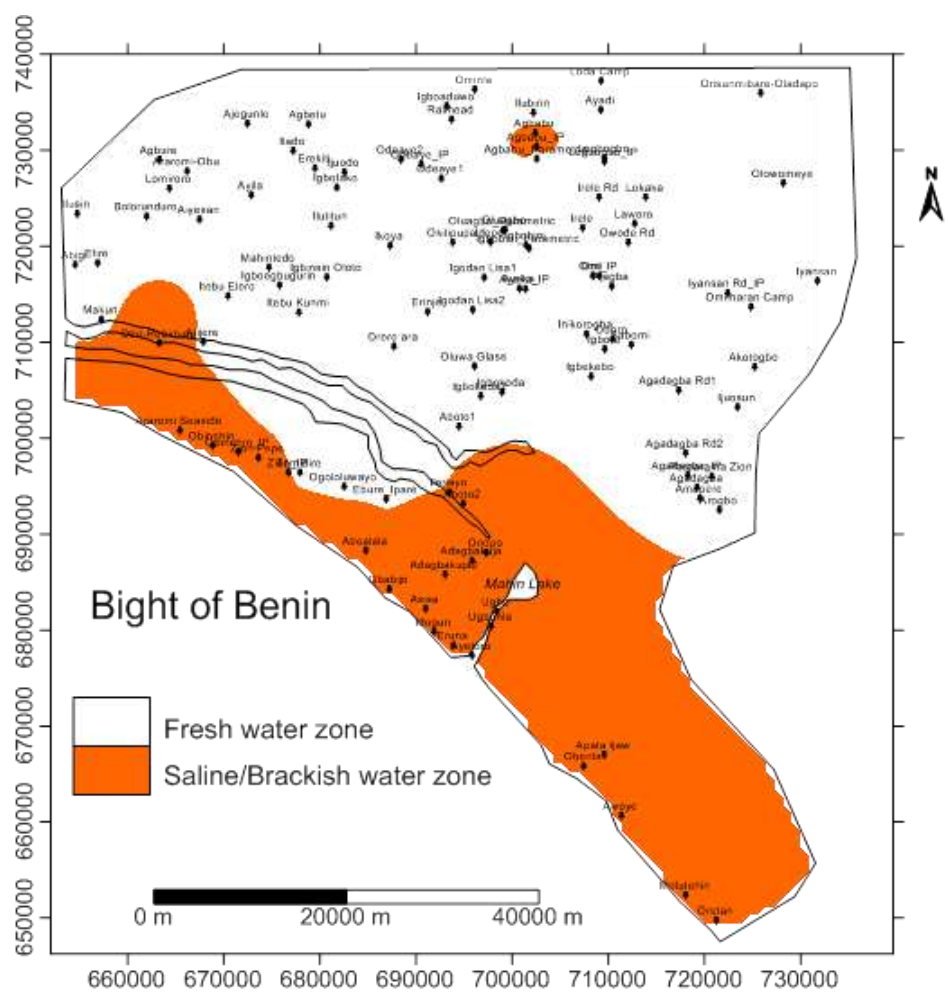

Figure 9: Map of saline water lateral extent of the study area 


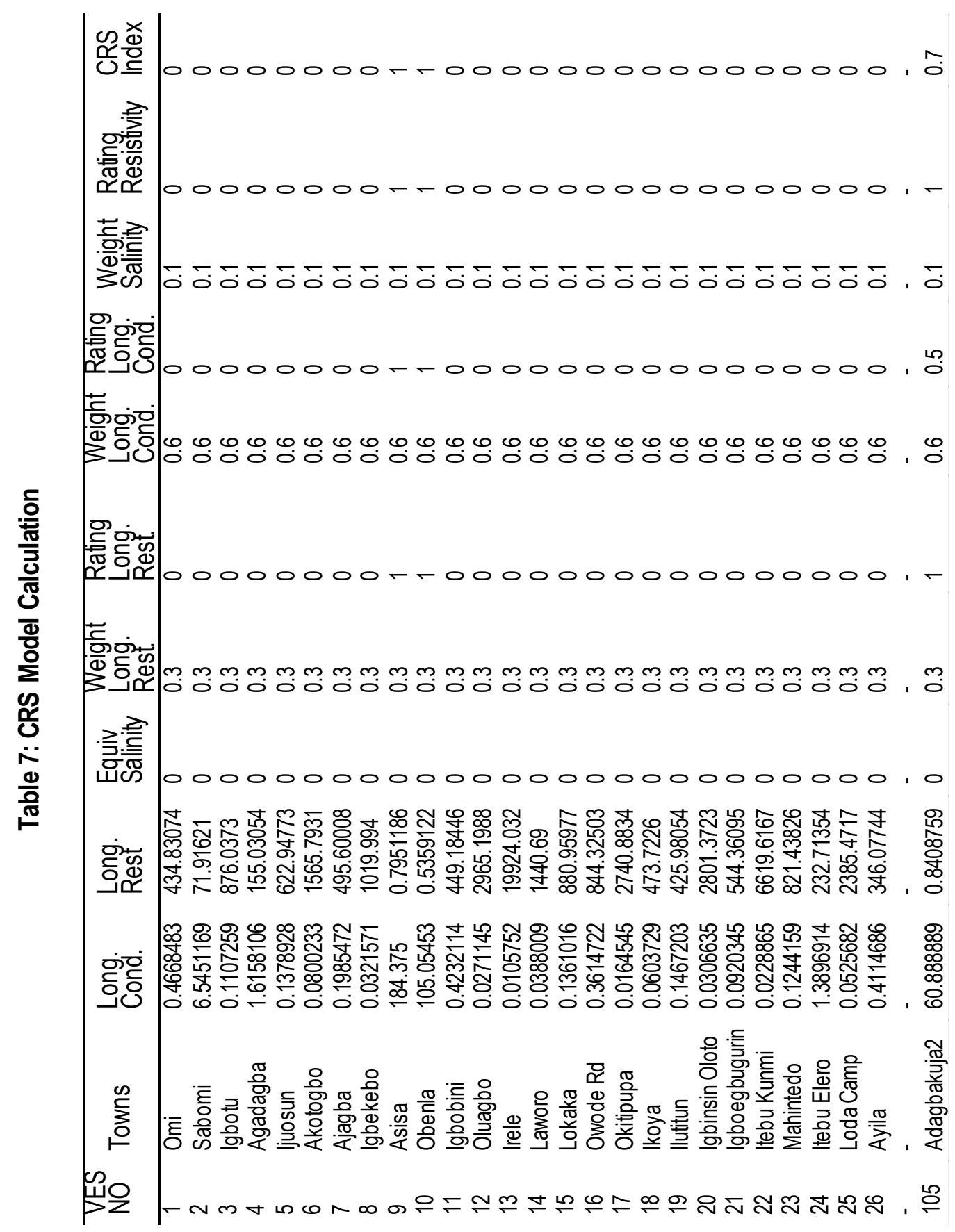

\section{CONCLUSION}

This study integrated 108 vertical electrical soundings (VES) data acquired using Schlumberger array technique and hydrochemical analysis of 61 water samples in delineating subsurface lateral extent of saline water intrusions into aquifers at the eastern part of Dahomey basin, Nigeria. The geoelectric survey results were presented as average longitudinal Conductance and average longitudinal Resistivity maps. The longitudinal conductance values vary from moderate to high (20 - 180 mhos) in the costal areas, while lower values (lesser than 10 mhos) were recorded in the mainlands. The average longitudinal resistivity values at the coastal areas and Agbabu, Legbogbo and Sabomi areas in the mainland were low to moderate $(0.26-41.7$ 


\section{Nigerian Journal of Basic and Applied Science (December, 2017), 25(2): 28-40}

ohm-m), while higher values (more than 60 ohm-m) were gotten from the mainlands. The hydro-chemical analysis values presented as equivalent Salinity map vary from $25.8 \mathrm{mg} / \mathrm{l}$ (Ode-Irele) to $2808 \mathrm{mg} / \mathrm{l}$ (Asisa), while higher values were obtained from Ugbo, Ugbonla, Odonla, Idogun and Ayetoro area in the southeastern part of the study area and at Agbabu in the north central. The three results were synthesized using CRS-model. The final CRS-model map showed that the saline water intrusion extended to $35 \%$ of the total area which covers; most part of the coastal area and Agbabu in the mainland. The presence of saline water at Agbabu in the central mainland is probably suggesting connate water, since there is no established path linking the sea to Agbabu area.

\section{ACKNOWLEDGEMENT}

The authors wish to acknowledgement many students of the Department of Applied Geophysics FUTA, who assisted during the field work stage of this work.

\section{REFERENCES}

Adepelumi, A.A. (2008). Delineation of Saltwater intrusion into the freshwater aquifer of Lekki Peninsula, Lagos, Nigeria. The 3rd Inter. Conference on Water Resources and Arid Environments and the 1 st Arab Water Forum, 15pp.

Adeoti, L., Alile, O. U. and Uchegbulam, $\mathrm{O}$. (2010). Geophysical Investigation of Saline Intrusion into Freshwater aquifers: A Case Study of Oniru, Lagos State. Scientific Research and Essays, 5(3): 248 $-259$.

Adeyemo, I.A., Omosuyi, G.O. and Adelusi, A.O. (2015). Hydrochemical investigation of saline water intrusion into aquifers in part of eastern Dahomey basin, Southwestern Nigeria. Journal of Environment and Earth Sciences (JEES), of International Institute for Science, Technology and Education (IISTE), 5(14): $176-189$.

Adeyemo, I.A., Omosuyi, G.O. and Adelusi, A.O. (2017). Geoelectric soundings for delineation of saline water intrusion into aquifers in part of eastern Dahomey basin, Nigeria. Journal of Geoscience and Environment Protection (GEP), Scientific Research Publishing, 5(3): 213 - 232.

Agat Laboratory (2008). Agat Laboratory Water Analysis Report Manual, www.agatlabs.com, 19p.

Ayolabi, E.A., Folorunso, A.F., Odukoya, A.M. and Adeniran, A.E. (2013). Mapping Saline Water Intrusion into the Coastal Aquifer with Geophysical and Geochemical Technique: The University of Lagos Campus case (Nigeria). Springerplus, 2(433): 1 - 14.

Batayneh, A.T. (2006). Use of electrical resistivity methods for detecting subsurface Fresh and saline water and delineating their Interfacial configuration: a case study of the Eastern Dead Sea coastal aquifers, Jordan Hydrogeology Journal, 14: 1277 - 1283.

Burke, K.C., Dessauvagie, J.F.T., Whiteman, A.J. (1971). The Opening of the Gulf of Guinea and the Geological History of the Benue Depression and Niger Delta Nature. Physical Science, 233(38): 51 55.

Chachadi, A.G. (2005). Seawater Intrusion Mapping Using Modified Galdit Indicator Model- Case Study in Goa. Jalvigyan Sameeksha, 20: 29 - 45.

Choudhury, K., Saha, D.K. and Chakraborty, P. (2001). Geophysical Study of Saline Water Intrusion in A Coastal Alluvial Terrain. Elsevier Journal of Applied Geophysics, 46: 189 - 200.

Jansen, J.R. (2011). Geophysical Methods to Map Brackish and Saline Water in Aquifers. Proceedings of the 2011 Georgia Water Resources Conference, April 11-13, 2011, University of Georgia. 4pp.

Jones, H.A. and Hockey, R.D. (1964). The Geology of Part of Southwestern Nigeria, Geological Survey Nigeria Bulletin, 31: 87.

Khalil, M.H. (2006). Geoelectric Resistivity Sounding for Delineating Saltwater Intrusion in the Abu Zenim area, West Sinai, Egypt. Journal of Geophysics and Engineering, 3: 24 - 251. 
Adeyemo and Omosuyi: Delineation of Saline Water Intrusion Lateral Extent Using

Klemme, H.D. (1975). Geothermal Gradient Heat flow and hydrocarbon Recovery In: A.G. Fischer and Judson, S. (Eds). Petroleum and Global Tectonics. Princeton University Press, 25 - 304.

Martinez-Retama, S., Flores, C. and CastilloGurrola, J. (2007). Saline Intrusion in Guaymas Valley, Mexico from TimeDomain Electromagnetic Soundings. Geofisica International, $46(3): 175$ - 98.

Samsudin, A. R., Haryono, A, Hamzah, U. and Rafek, A.G. (2008). Salinity Mapping of Coastal Groundwater Aquifers using Hydrogeochemical and Geophysical Methods: A case Study from North Kelantan, Malaysia. Environmental Geology, 55: 1737 - 1743.

Satriani, A., Loperte, A. and Proto, M. (2011). Electrical Resistivity Tomography for Coastal Salt water Intrusion Characterization along the lonian Coast of Basilicata Region, Southern Italy. IWTC15, 15 th International Water Technology Conference, Alexandria, Egypt, 12pp.

Okosun, E.A. (1998). Review of the Early Tertiary Stratigraphy of Southwestern Nigeria. Journal of Mining and Geology, 34: 27 - 35.

Omosuyi, G.O. (2001). Geophysical and Hydrogeological Investigations of Groundwater Prospects in the Southern Part of Ondo State, Nigeria. PhD Thesis, Department of Applied Geophysics,
Federal University of Technology, Akure, Nigeria, 195pp.

Omosuyi, G.O., Ojo, J.S. and Olorunfemi, M.O. (2008). Geoelectric Sounding to Delineate Shallow Aquifers in the Coastal Plain sands of Okitipupa Area, Southwestern Nigeria. The Pacific Journal of Science and Technology, 9(2): 562 - 577.

Omoyoloye, N.A., Oladapo, M.I. and Adeoye, 0.0. (2008). Engineering Geophysical Study of Adagbakuja Newtown Development SW, Nigeria. Medwell Online Journal of Earth Sciences, 2(2): 55 - 63.

Oyedele, K.F. and Momoh, E.I. (2009). Evaluation of Seawater Intrusion in Freshwater Aquifers in a Lagoon Coast: A Case Study of the University of Lagos Lagoon, Akoka, Nigeria. New York Science Journal, 2(3): 32 - 42.

Nigeria Geological Survey Agency (2004). Geological Map of Southern Part of Ondo State

Rahaman, M.M. and Bhattacharya, A.K. (2014). Saline water Intrusion in Coastal Aquifer: A case study from Bangladesh. Journal of Engineering, 4(1): 7 - 13.

Zohdy, A.A.R., Eaton, G.P. and Mabey, D.R. 1974. Application of Surface Geophysics to Ground-Waterlnvestigations, In Techniques of Water-Resources Investigations of the United States Geological Survey. Book 2, Chapter D1. 63p. 